\title{
Rock Engravings and Paintings: Rethinking of the Cupules, Gongs, and Grinding Hollows of Siuyu and Ughaugha in Singida East (Tanzania)
}

\author{
Makarius Peter Itambu1 ${ }^{*}$, Alfred Mulinda', Allan Bukenya ${ }^{3}$, Charles Bernard Saanane1, \\ Emmael Sassi Gibinagwe', Mariam Bundala1, Pastory Magayane Bushozi ${ }^{1}$
}

\author{
${ }^{1}$ Department of Archaeology and Heritage Studies, University of Dar es Salaam, Dar es Salaam, Tanzania \\ ${ }^{2}$ Department of Foreign Languages and Linguistics, University of Dar es Salaam, Dar es Salaam, Tanzania \\ ${ }^{3}$ Pallottine Missionary Siuyu Parish (S.C.A), Singida, Tanzania \\ ${ }^{4}$ Dar es Salaam University College of Education, Dar es Salaam, Tanzania \\ Email: *mcpeter7@gmail.com
}

How to cite this paper: Itambu, M.P., Mulinda, A., Bukenya, A., Saanane, C.B., Gibinagwe, E.S., Bundala, M. and Bushozi, P.M. (2018) Rock Engravings and Paintings: Rethinking of the Cupules, Gongs, and Grinding Hollows of Siuyu and Ughaugha in Singida East (Tanzania). Journal of Geoscience and Environment Protection, 6, 160-180.

https://doi.org/10.4236/gep.2018.66012

Received: January 29, 2018

Accepted: June 26, 2018

Published: June 29, 2018

Copyright $\odot 2018$ by authors and Scientific Research Publishing Inc. This work is licensed under the Creative Commons Attribution International License (CC BY 4.0).

http://creativecommons.org/licenses/by/4.0/

(c) (7) Open Access

\begin{abstract}
Our recent archaeological expeditions in the Siuyu and Ughaugha wards of Singida eastern province have recuperated the very compelling rock engravings (petroglyphs) that weren't reported in Tanzania before. Archaeologically, Singida's fame emanated from her endowments of rock paintings. However; during this research, we did discover rock cupules, gongs, and grinding hollows art together with rock paintings (pictographs) that have opened up a new avenue for rock art studies in Tanzania. We carried out intensive site surveys around four sites namely Siuyu, Ngaghe, Misimbwa and Ughaugha B with the aims of solely examining, recording, and documenting archaeological artifacts on the surface in order to research the cultural and behavioural patterns of early humans in the Singida region. Surveys also enabled us to locate suitable areas where future excavations would be established. In some cases, ethnographic enquiries were employed to get supplementary information on the present-day use of rock art sites. Besides, we interviewed local people to assess their general understanding of the presence of more sites or helping in locating, and discovering new sites. Through ethnographic inquiries, we discovered several sites with substantial number of rock engravings that were never document by any researcher. On top of that, this study reports other archaeological potentials of the region by describing in detail their significances for future research undertakings. Additionally, this paper article reports on the occurrence of Middle Stone Age (MSA) archaeological assemblages from the open-air site and the presence of grinding hollows and rock cupules (Siuyu complexes) in central Tanzania for the first time.
\end{abstract}




\section{Keywords}

Rock Engravings, Rock Paintings, Archaeological Expeditions

\section{Introduction and Background Information}

The Singida region's antiquities and and its patrimonies have been of paramount importance in archaeological studies since colonial period, however; most of its prehistory was in obscurity and not so much unravelled by the pioneers of archaeological research in Tanzania. The archaeological research in central part of Tanzania has witnessed a gradual proliferation over the last three decades. Thematic wise, various research endeavours have been broad and varied, there appeared to be a hiatus towards certain research themes and segments of the country [1] [2] [3] [4] [5]. Geographical zonation has over the years tended to favour certain segments of the country especially the northern and rift valley region, and the coast and littoral [6]. Research in the central regions of Dodoma and Singida has been rather sparing by comparison to other regions of the country, often times with a perpetual thematic bias towards its "vanishing" rock art of Kondoa and the transition from Later Stone Age to Iron Age cultures [7] [8]. No particular research project in this archaeologically impressive region that had so far tried to document and record the petroglyphic art of the Singida region. The archaeological findings we have unearthed will probably come to astonish many scientists in the near future, due to the fact that this region was ignored for many decades by the fore-runners of archaeological research in Tanzania. Recent efforts by Itambu et al., 2013-17 have recovered Middle Stone Age (MSA), Later Stone Age (LSA), Iron Age (IA), and the Historical Period (HP) cultural materials that are crucially significant in reconstruction of early human's technological transition and complexity of stone tool use cultures that were never reported previously from this part of the country.

Available literature on the archaeology of central Tanzania reveals that very little attempts have been made to unravel the archaeological potentials of Singida region since the efforts of Masao (1979). Masao's (13) research encompassed surveys and excavations at various rock-shelters and also incorporating a study of the indigenous rock art, informed his conclusions on the later prehistory of central Tanzania mostly basing on data from Singida northern axis. Most parts of Singida east were remained unexplored until Itambu et al. (2014) decided to wage several archaeological expeditions to the eastern axis, the works that produced these significant archaeological data.

Interestingly, though Masao's research did examine the Later Stone Age (LSA) of central Tanzania to the fore, the bulk of the rock-shelters (rock art sites) mentioned in his survey of Singida district were only studied with respect to the rock paintings they contained and no further studies have since been carried out the- 
reinafter [9] akin, excavation under the rock shelters wasn't carried out. The paucity on archaeological investigations on stratified subsurface cultural and archaeological materials in Singida is unquestionable. However, our current research initiatives are trying to fill the gap by examining various aspects of Singida east prehistory, particularly its MSA, LSA, and IA to Historical cultures. This paper therefore highlights the new developments on our archaeological investigations in central Tanzania (Singida region), and subsequently reporting the new discoveries on rock art traditions.

\section{Regional Area Profile}

Singida is a landlocked region located in the middle of the country. It borders the regions of Simiyu and Shinyanga to the northwest, Manyara and Arusha to the northeast, and Dodoma to the east. To the southwest, bordered by Iringa, Mbeya to the southwest and the Tabora region is to the west (Figure 1). The region is one of the most compelling areas of geological and archaeological research in Tanzania as indicated by her impressive and massive, isolated hills, inselbergs and granite outcrops, the land of small and large plateaus, and escarpments

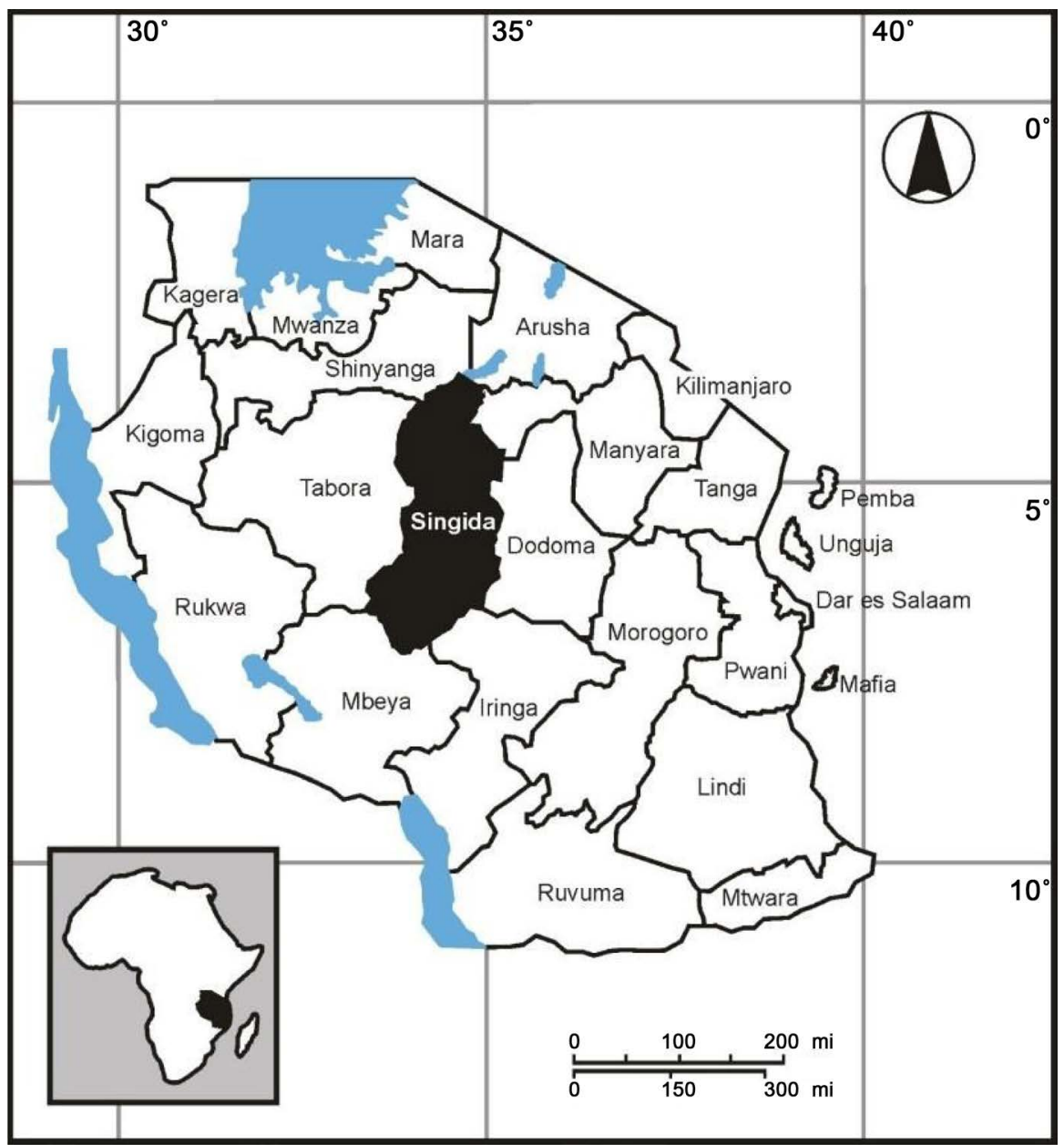

Figure 1. Map of Tanzania showing location of Singida region (modified from Ekeke 2010). 


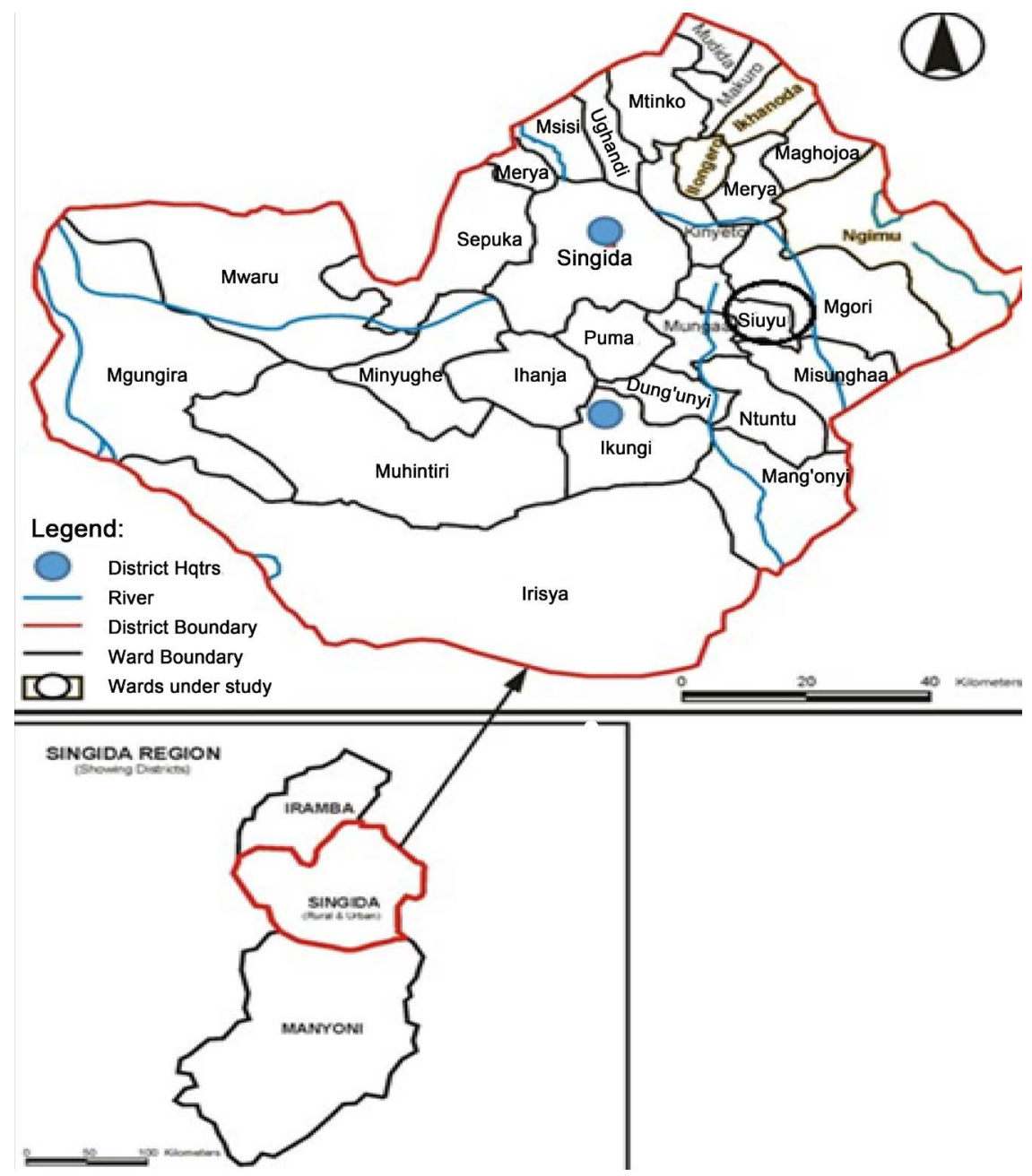

Figure 2. Map of Singida showing the study area (modified from Ekeke 2010).

that form a unique and beautiful natural landscape [9]. It lies in the semi-arid zone of Tanzania's central plateau between longitude $33^{\circ} 24^{\prime} \mathrm{E}$ and $35^{\circ} 1^{\prime} 2 \mathrm{E}$ and latitude $3^{\circ} 42^{\prime} \mathrm{S}$ and $7^{\circ} 06^{\prime} \mathrm{S}$ (ibid).

Our research focused on the Singida eastern axis in the Ikungi district, specifically in areas surrounding and adjoining Siuyu ward. The Ikungi district is one among the five (5) districts forming the Singida region. This is a newly established district formed in March 8th, 2013 through government gazette no. 87. The Ikungi district is within $4^{\circ}$ to $6^{\circ}$ latitudes south of the equator and between $34^{\circ} 45^{\prime}$ to $35^{\circ} 45^{\prime}$ East of Greenwich meridian (tambu and Hongoa 2016). The district borders Uyui district of Tabora region in the south, Singida municipal and Singida rural from the north, Iramba from the northwest, Chemba and Kondoa from the northeast and Manyoni from the south. The southwestern zone that borders Uyui and Manyoni districts has fertile soils while the rest has less fertile (sandy soils) which is mainly suitable for production of semi-arid adapted crops (Itambu and Hongoa 2016) Three of the four sites where this research conducted found in the eastern part of Ikungi district. Of the four sites, 
three sites namely Siuyu, Nghaghe and Misimbwa are located in the north-central portion of the district, while the fourth one, Ughaugha B lies on the weastern corner of the Singida municipal district (Figure 2). The Ikungi district is made up of four divisions namely Sepuka, Ikungi, Ihanja, and Mungaa. The three sites are situated in Siuyu ward of Mungaa division [6].

\subsection{Vegetation \& Wildlife}

The vegetation cover and topography of Singida region covers part of a high plateau overlooking the Wembere depression on the west and the rift valley on the east. This plateau of an average elevation of 1000 meters extends from the centre toward the south and south west of Singida municipality, while in the northwest of the region the Iramba plateau rises to an elevation of about 1500 meters above sea level. The undulating landscape is punctuated by isolated hilltops that are capped by small boulder outcrops and rocky hills of granite with a relief of up to 30 metres high. Dry forests, shrubs, bush savannah and occasionally grassy plains surround these rocky highlands [8].

The prototype vegetation of Singida region is consisting of savanna woodlands (largely miombo or Brachystegia sp.) with small pockets of montane forests and savannahs . Contemporary intensification of tree clearing for agricultural activities, timber, and wood for house construction, firewood, and charcoal burning have greatly reduced the amount of natural biomes. In the study area, savanna woodlands composed of Brachystegia sp. still exist in Ngimu-Mugori, Mwisi, Lighwa, Ntewa-Ntutu, ThrauMang'onyi and Musule-Misughaa, though threatened by human activities. Animal husbandry and other anthropogenic activities have reduced the natural habitats and the number of wild animals. The larger part of the region's landscape composed of plateaus and isolated rocky hills with very sparse vegetation. Singida district is dominated by bushland and wooded grassland and scattered bushes covering a very little percentage of the ground.

The ground cover is dominated by short grasses such as Hyparrhenia spp., Heteropogon contortus, Aristida kenyensis, Hypachne schimperi, Eragrotis spp., and Dicanthium spp. The woodland vegetation includes trees such as Acacia tortillis, A. Drepanalobium, Euphorbia, Eucalyptus globules, Brachystegia spp., and Cassia spp. The endemic vegetation of Singida is believed to have consisted of savannah woodlands with small patches of thickets and shrubs shrubs [8] as being representative of the ancient flora and fauna of the area. Currently, much of the fauna is made up of hyenas, dik-diks, and small mammals such as hedgehogs and rodents. Our ancestors (prehistoric people) probably selected mountainous landscapes for arty executions as the painted arts can probably survive longer [6] or for security reasons/defence as the geomorphology of the landscape discourages and limits access to potentially dangerous wild animals.

\subsection{Climate (Rainfall \& Temperature)}

The Ikungi district experiences even temperatures, with minima and maxima of 
$15^{\circ} \mathrm{C}$ and $30^{\circ} \mathrm{C}$ respectively. Nonetheless, there has been notable rise in ambient temperatures in the last four decades. The annual rainfall ranges from $600 \mathrm{~mm}$ to $700 \mathrm{~mm}$. These climatic conditions favour the production of certain types of semi-arid adapted agricultural crops [10]. The district has three main agroeconomic zones, namely; the northern zone, the south west, and the eastern zone that lies within the vicinity of the Rift Valley. The eastern Singida axis, just as a large portion of Singida region, is typically of aridity climates as the amount of rainfall decreases from North to South of the region. The average annual rainfall ranges between $500-800 \mathrm{~mm}$. The higher and more reliable rainfall is recorded in the northern part of the region where rainfall exceeds $750 \mathrm{~mm}$ in most seasons. The lowest rainfall is usually recorded in the western part of Manyoni district. The rainfall in this area is as low as $500 \mathrm{~mm}$, while the highest rainfall recorded in Iramba plateau and the North-eastern part of Iramba reaches $800 \mathrm{~mm}$. The rainy season usually starts from mid-November to late April or early-May. The temperature in the region ranges between 15 and 30 degrees Centigrade depending on the season and altitude. The coldest month in the year is July, while the hottest is November (see [11]). Relative humidity at noon rises from 36 percent in the driest month to 58 percent during the wet seasons. Evaporation is almost similar in the region and averages close to $2000 \mathrm{~mm}$ annually although it is a bit higher in the rift valley areas. It is lowest in April as it goes down to 1400 $\mathrm{mm}$. Wind speed is usually higher in Singida and it is phenomenal during the dry season, i.e. between May and October, usually result in dry and unfriendly windy weather.

\subsection{Geology, Soils, and Drainage Systems}

The Singida region lies at the southwestern extremity of the Eastern Rift system which is characterised by the raised blocks and fault scarps form significant morphological features in the area. The depressions between the uplifted blocks often show discharge-less basins. The superficial deposits range in age from Miocene to Recent. Youngest are alluvial fans and talus slopes now in process of formation [11]. In most parts of the study area, the rock shelters with archaeological artifacts occur mainly in the highlands, and they are commonly scattered along the Precambrian granite rock outcrops.

The common and ubiquitous rock formation in Singida is the basement system and its derivatives. A granitoid shield together with mobilised granite predominates in Singida region [11]. The extensive granitisation of rocks has brought about the formation of migmatites, granites and related rocks, which together make up what is known as the granitoid shield (ibid.). The mobilized granites are intrusive granites presumably brought about as a result of large scale emplacement of "younger" granites into Nyanzian and Kavirondian rocks [11]. Singida has a series of valleys, depressions and rivers catchments, which form the basis of the land drainage system and soil types. The granite and batholithic rocks, peneplains, and volcanic plateaus result in fertile clay loamy soil on top 
and sandy clay loams to sand pebbly surface materials down the catena. Generally, the geology, soils, and drainage patterns of Singida consists of the basement rocks which are type of Dodoman system which are ubiquitous in the region and they are part of the Dodoman system, formerly referred to as the Lower Basement Complex [11]. These rocks consist of a complex of pellitic schists, granitic gneisses and migmatites, ranging in mineral composition from potassic granite to diorite.

\subsection{People \& Economy}

The eastern zone of the region is occupied by the East African Rift Valley system that is bordered by Kondoa district and Singida municipality. This zone occupies Ikungi and Mungaa divisions. The Wanyaturu (Turu/Rimi/Arimi people) are the predominant tribal groups in the area, they are small-scale agriculturalists and cattle herders that are generally living in cleared areas close to the margins of the woodland. The surface of Wahi-Arimi, the sub-tribal area in which this study was conducted (Siuyu Ward) is desiccated and undulated with hills, ridges, and bottom valleys of marshy land that are suitable for growing potatoes. It is estimated that about 15 percent of the workforce in the district engages in other activities such as timber, fishing, small industries (sunflower oil processing) and small scale mining (salt) activities. This part of the Singida eastern axis is primarily settled by Wahi and Anyamunying'anyi-Wanyaturu. Their livestock are grazed on the open lands around the village or in the nearby forests until the grass is gone; otherwise the marshes are expected to support them during the dry seasons of June to November [12].

Despite the fact that there are other economic activities that are taking place in this area, agriculture is still the largest single sector in the economy of the district, producing almost $60 \%$ of the Singida region's wealth of goods and services. Roughly, it is estimated that $90 \%$ of the residents of Singida region depend on agriculture as the main source of their livelihood. The major crops cultivated annually include: maize, sorghum, bulrush millet, sweet potatoes, and beans. Sisal (Agave sisalanna) is still widely cultivated in the area, not as a cash crop export as in the past, but as fence to demarcate farmlands from grazing fields. Animal husbandry is another aspect of the economy of the people. It ranks as the second most important sector in the region's economy after agriculture. The animals bred are mainly cattle, donkeys, goats, sheep, and chickens (domestic fowls). Fishing is also among the economic activities in Singida district owing to the large water bodies in the area. The fish species exploited are mainly of the cichlids family (Cichlidae), of which the tilapia (Tilapia mossambica) is most prominent in the area. The available statistics indicate that in 1999 fisheries production were 220 tonnes, while in 2000 the production grew to 370 tonnes, but fell in 2001 and 2002 from 70 to 40 tonnes.

The Ikungi district is chiefly inhabited by agro-pastoral Wanyaturu that are forming about $95 \%$ of the total population [12]. The remaining 5\% is composed 
of the hunter-foragers Wasandawe, and the pastoral Wabarbaig and Wadatoga tribes. Although agropastoralism has been practiced in this area, presently crops husbandry is the chief economic activity with about $90 \%$ of the residents depending on it as the source of their livelihoods. Predominantly, the Singida rural and Ikungi areas among Wanyaturu are deeply attached to livestock and simple cropping systems. The shifting cultivation of sorghum, millet, and fingermillet forms an integral part of their daily diet. Other agricultural crops grown in this part include sweet potatoes, sunflower, beans, groundnuts, and maize. On top of that, one can argue that sunflower cultivation within homesteads has attained a status of a dominant cash crop. This cash crop, in contrast with the past, is acting as a substitute to food crops, due to the fact that it superbly withstands the arid soils of the region. The limited resource-base and poor aridic soils, and variable rainfalls has resulted in food shortages in the months of December, January, and February [12].

The northern zone bordering Singida district council and Singida municipal, made up of the Ihanja and Sepuka divisions, has very fertile gravel-loamy and clay soils that favours the production of various crops. Agricultural crops produced in this part of the region include sorghum, finger millet, cassava, sunflower, onions, millet, sweet potatoes and lentils (dengu). The eastern zone is occupied by the East African Rift Valley and is bordered by Kondoa district (Dodoma region) and Singida municipality. This zone occupies Ikungi and Mungaa divisions. The surface of Wahi-Arimi, the sub-tribal area in which this study was conducted (Siuyu and Ughaugha Wards) are desiccated and undulated with hills, ridges, and bottom valleys of marshy land that are suitable for growing potatoes. It is estimated that about 15 percent of the workforce in the district engages in other activities such as timber, fishing, small industries (sunflower oil processing) and small scale mining (salt) activities. This part of the Singida eastern axis are primarily settled by Wahi and Anyamunying'anyi-Wanyaturu. Their livestock are grazed on the open lands around the village or in the nearby forests until the grass is gone; otherwise the marshes are expected to support them during the dry seasons of June to November. In some villages, however; there are forest reserves that provide not only building materials, medicine, and parts for tools, but also fuel [12].

Customarily and frequently, this is gathered by the women, while men are responsible for traditional houses construction, other construction work, and cattle grazing. Unfortunately, the agricultural sector has been negatively affected by a number of factors such as arid climatic conditions (dependence on rain fed agriculture) and poor physical infrastructure, particularly roads. As a result, people's incomes in the district has been affected. The average farm size per peasant household is 5 acres of a subsistence farm. At this moment in time, a by-law has passed stipulating a district "by-law" that requires a farmer to have 2 acres of each food and cash crops respectively to ensure food security. They are encouraged to grow semi-arid climate tolerant, and disease-resistant crops such 
as cassava and sweet potatoes because of the drought nature and general episodic drying trends of the region [12].

\section{Materials and Methods}

The sites where the study was undertaken were discovered by Itambu in 2013, Itambu and Hongoa in 2016, whereby they documented two of them [12]. We revisited these two sites and discovered new two sites that were not reported by any researcher before. These sites have rock paintings, rock engravings and a good number of surface scatter of lithics and other archaeological artifacts. Our surveys were restricted to the Ikungi district and her adjoining neighbouring wards. On rocky hilltops, such as Ngaghe and Misimbwa hills, and Ughaugha B; surveys were selectively carried out due to the roughness of their terrain and of the rocky landscape which did not provide us with easy trekking. In areas with moderate to relatively flat surfaces, as was the case in Siuyu-Urimi, a systematic survey was conducted whereby 18 University of Dar Es Salaam's Archaeology Class (Students in field practicum) were spaced apart i.e. 2 meters away from each other, walking on a straight line at least $1-2$ Kilometers from the rock outcrops to the hamlet farmlands, and across the uncultivated landscapes of the area. They were identifying, documenting, recording, and collecting some artifacts such as surface scatters.

GPS readings and panoramic digital camera photos of areas with higher concentration of surface scatters and exposed cultural materials were taken. Methodologically, the study combined the use of informants, ethnographic inquiries, and traditional archaeological surveys in discovering the sites. A total of four sites were recorded and documented. Given the mountainous nature and the rough terrain of the Precambrian granitoid rocks, time, logistics, and financial constraints, the use of informants (Plate 1) proved to be the most productive method of which it yielded three of the four rock art sites that were not discovered previously.

The Siuyu Ward ( $\left.S 5^{\circ} 07^{\prime} 59.00^{\prime \prime}, E 39^{\circ} 46^{\prime} 0.01^{\prime \prime}\right)$

Siuyu is an administrative ward in the newly Ikungi district formerly known as Singida rural district. According to the 2002 census, the ward had a total population of 8632 [12] but due to the improvement of social services, the population size is estimated to be presently around 18,000. Around the vicinity of Siuyu ward there is a bunch of inselberg hills, kopjes (Plate 2), and ridges that are separated by mbughaa bottom valleys (black-clay soils), common everywhere in the Singida eastern axis. They are also marked by the ubiquitous granite outcroppings, sometimes of giant proportions, that appear here and there in every village (Ngong'o A Urimi as the most popular one [12]. The internal drainage of the Siuyu created marshy lands and swamps, traditionally called "mbuugha" (black cotton soils/cracking clays). These clay-black cotton soils are composed of calcareous (ibid). These black fissured clays vary greatly in size-from small patches which dry out quickly when the rains stop, to giant expanses, especially in the 


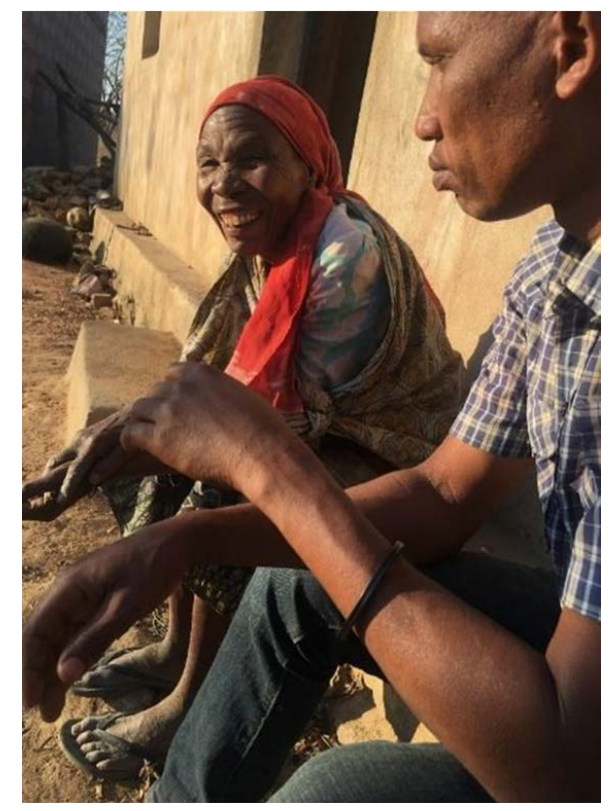

Plate 1. Ethnographic inquiries with Cecilia Ikimbia Ghuo (left), and Bonaventura W. Makiya.

Singida depression, some of which, like Mugori and Muyanji dams hold surface water perennially. Since most depressions are shallow and hold only a little surface water, the swamp grasslands "Inyee" can be used for grazing during dry seasons (i.e. Mudenku, Malelemi, Nali-Nghage Donye). These unusual semi-arid conditions, combined with the fact that the swamps are numerous and provide a permanent water-supply, has had been a highly significant factor in the consolidation of sedentary settlements that led to the collapse of nomadic pastoralism.

The livelihoods of the majority of inhabitants of Wahi-Arimi in Siuyu (Figure 1) are mainly dependent on agriculture (crop production) and livestock keeping and, in particular, indigenous poultry. To a lesser extent, horticulture (neighbouring permanent swamps), and small business enterprises that forms the extra-economic activities of most of the Ikungi inhabitants. The district economy is heavily tilted towards agriculture as more than 85 percent of the population are engaged in crop cultivation and livestock keeping [12]. However, the level of agricultural mechanization is very low with large a proportion of the farmers solely depending on the traditional hand hoe for tilling arable lands. In all aspects of life, patriarchy is highly dominant in Singida east. The men are the decision-makers and women are mainly responsible for children-rearing and other domestic duties. However, women's workloads in the study area is not correlative to men's daily duties due to the fact that women are more productive, chief producers, and important contributors to household incomes. Our research identified that most of the archaeological sites in Singida eastern axis look like Kondoa Irangi rock art (Plate 3(a), Plate 3(b)) localities. They appear high up on silent bush covered hillsides, invariably overlooking some plains, a valley or a river. Seldom do these sites occur on low-lying ground and such is also the case 


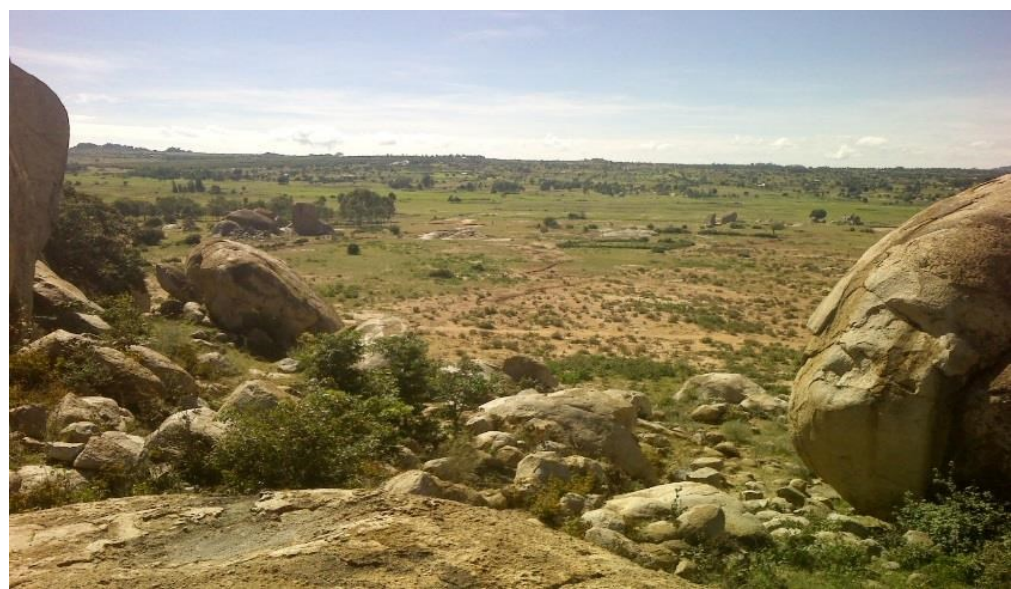

Plate 2. A panoramic view of Siuyu granitoid outcrops.
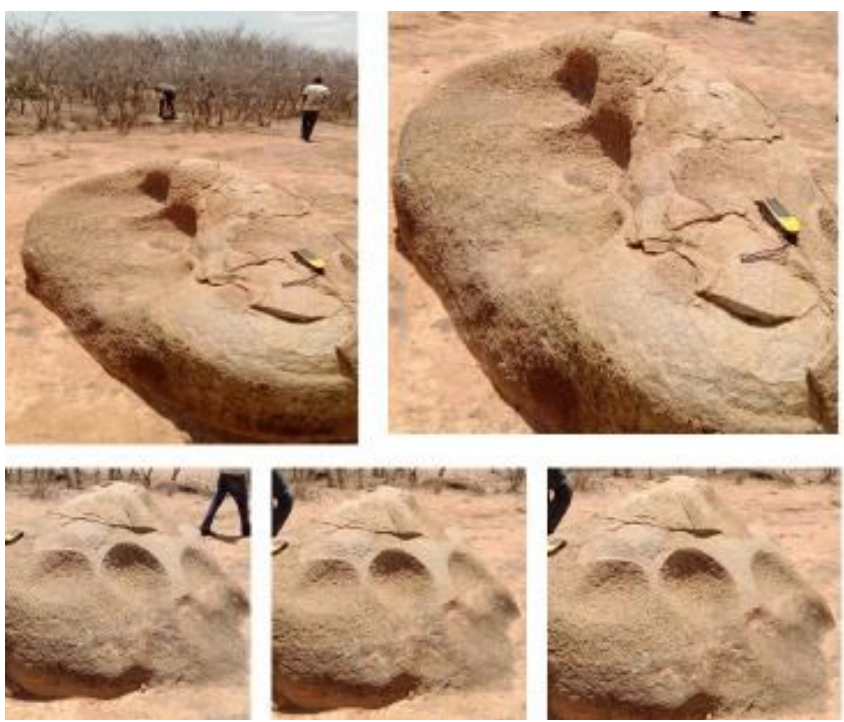

(a)

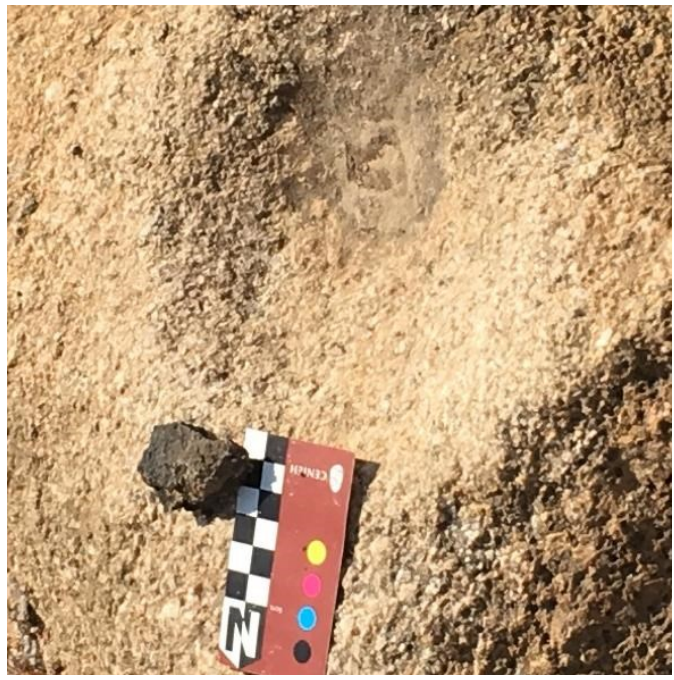

(b)

Plate 3. Rock cupules (a), and (b) grinding hollows of Ngaghe (Siuyu complexes). 
with most of the South African rock art sites. Several reasons have been provided for such locations to have been favored. Hill slope sites commanded wide, lovely views out over far reaching plains and immediate areas around providing the best vantage point, for watching for game or for self-defence against their foe [12]. The rock engraving art (petroglyphs) of this area is categorized into three rock engraving traditions; cupules, grinding hollows and gongs (Plate 3(b), Plate 4).

\section{Field Work Results}

\subsection{Survey Results: Ngaghe Hill Grinding Hollows, Cupules (Siuyu Complexes)}

Interestingly, for the first time, "Siuyu complexes" rock art tradition, referred herein as the cupule Art of Singida, Tanzania is reported (Plate 3). No any researcher in Tanzania has previously reported the presence of the cupules art in Tanzania, but this art has been reported in India Bednarik in 1994, who claimed that it is dated to at least 30,000 years old.

However, the grinding hollows like that of Singida has been reported recently by Saanane Bernard [13] recently in Simiyu district of north-western Tanzania. These grinding hollows and cupules might have been used to process medicinal plants, herbs, tubers, and nuts by our ancestors. Our ethnographic inquiries didn't yield enough and detailed information on the present-day use of the cupules or grinding hollows by the local community. However, using indigenous
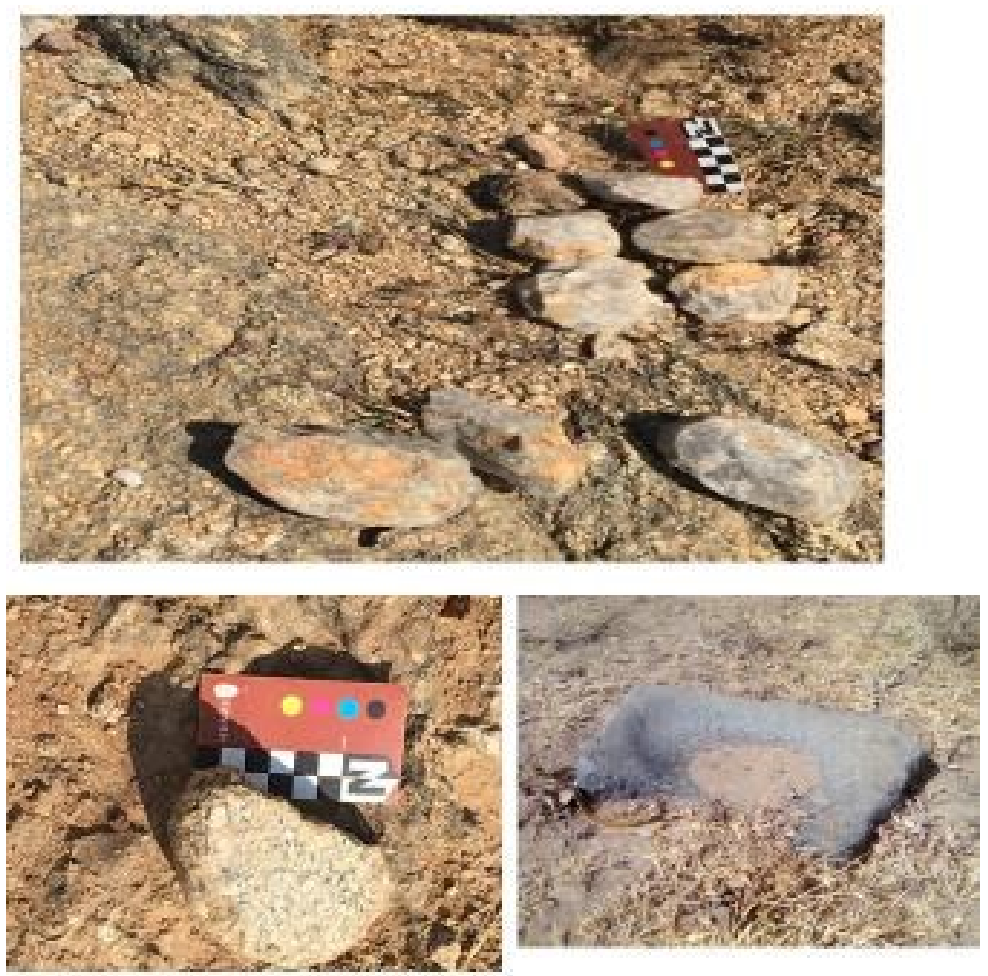

Plate 4. Archaeological materials on the surface of Ngaghe site. 
knowledge i.e.(the main author Makarius Itambu) is from this area, he believes that these cupules and hollows on rock surfaces were used to process medicinal herbs, plants, and nuts through a repeatedly activity of heavy striking, pounding, and grinding on rock surfaces (see Plate 3 \& Plate 4 and Appendix 1). The site is surrounded by Precambrian granite-kopjes and inselbergs, and the general vicinity of the rock shelters and its landscape is largely composed of LSA stone artefacts, slag and potsherds (Plate 4). There is an occurrence of Middle Stone Age (MSA) archaeological assemblages, historical period features and structures from the open-air sites of the study area.

\section{Ughaugha Rock Paintings and Rock Gongs (UTM: 9458320)}

Rock gongs are believed to be the earliest evidence we have on hand of what our ancestors might have listened to music. What is left with us by our ancestors is some traditional forms of musical instruments like these rock gongs we found in Ughaugha village. The gong rock art in the Singida region Ughaugha B's stone kopjes. It is probably the oldest forms of traditional art instrument invented on rock surfaces that were made on top of the larger flattenedsurface rocks and its uniqueness tell us a story of how early humans invented music by playing simple melodies on the metallic sounding rocks. The pitted surface of the "Gong Rock" in Ughaugha B is a testimony to its use by the Turu/Rimi tribe to send sounding melodies and joyful messages to the neighbouring communities within this ethnic group or any other ancestors than the Rimi since ancient times. There are two rock gongs at Ughagugha B kopjes, kids play stones (a game), and flat surfaced rocks of which its steep slope children used to slip down from the rock, a game that is popularly known as Musietreo in Turu language. This word can be literally translated as slipping/sliding on rocks (top-down sliding) while sited on small slab or plant leaves by kids aged between $5-16$ years old. This is one of the most popular traditional sport among the juveniles in this region (Plate 5). They are located just $50 \mathrm{~m}$ north of $\mathrm{Ng}$ ' ongo A Gifandwa $\mathrm{A}$, and the actual name for rock outcrops that contain these granite boulders is $\mathrm{Ng}$ ongo A Musietreo. This name is derived from the Turu/Rimi language i.e word "Sietrea" which means to slide or swiftly slip down.

\section{Rock Paintings (Pictographs)}

Importantly, we did extensive surveys towards granite outcrops and all rock boulders of Siuyu village and her neighbouring villages in order to discover more archaeological sites and rock art. The walkover surveys covered at least 6 hamlets. During this exercise, we systematically surveyed rock shelters in Ng'ongo A Urimi, Ghodou, Ifoneo, Munini, Misimbwa, Itramuka outcrops in Siuyu and Itraghatra villages, also we did extend our walkover surveys to Ng'ongo A Gifandwa A, B as well as Ng'ongo A Usoo of Ughaugha B rock outcrop complexes. In Ughaugha $B$ sites, we discovered both rock engravings and rock paintings that belongs to "Hunter-foragers" rock art tradition. Two rock painting sites were documented in Ughauga B rock shelters and overhangs at Ng'ongo A Gifandwa $\mathrm{A}$ and $\mathrm{B}$. 

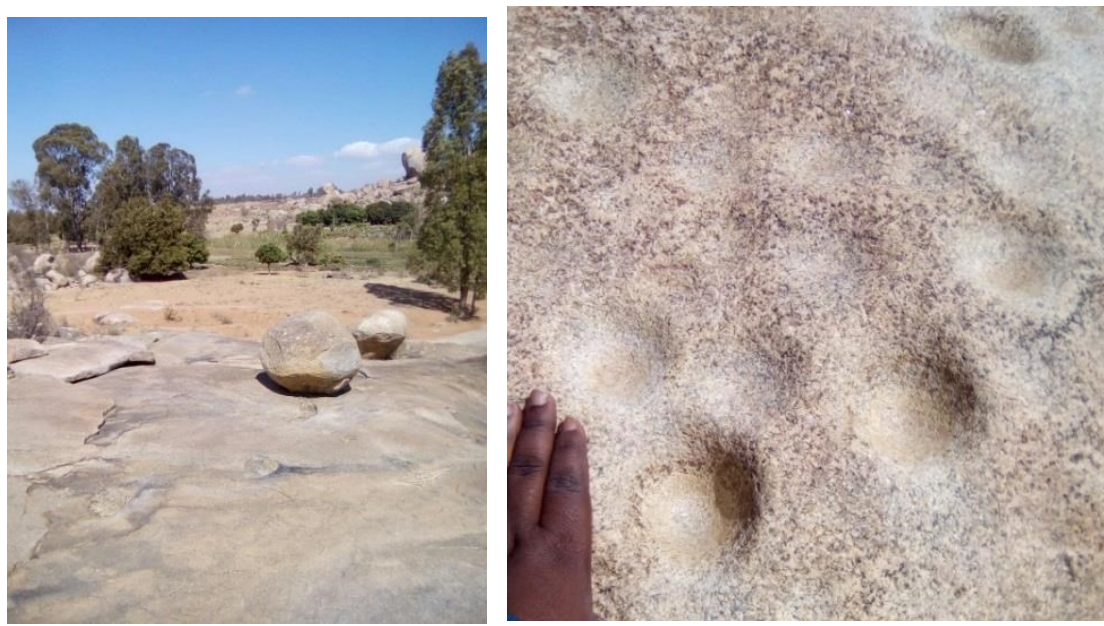

Plate 5. Gongs art in Ughaugha B sites.

\section{Ng'ongo A Gifandwa A (Elevation 1666m m: N0705251, N 1458518)}

This is a massive rock rock-shelter facing north and it is located on the flanks of Ughaugha B village marshlands that also marks the boundary between Ughaugha A \& B villages, about $1 \mathrm{~km}$ east of Ughagha Primary School. The site is surrounded by granite-kopjes and its entire landscape is covered by the dense surface scatter of LSA stone artefacts, slag and pottery. The painted shelter's wall covers an area of about $3.30 \mathrm{~m}^{2}$. We recorded over 8 animal figures, most of which represent naturalistic animals. Animals represented include antelope and elands. Animals are depicted in a naturalistic style and some of them are placed over others. Other depicted figures include parallel lines, black dots, concentric circles and one fainted head-dresses. The majority of the paintings are done in red, but few of them are in black. Although the rockshelter of Ughaugha are located on the outskirts of Singida town, most of the painted figures are in a fair state of preservation. The eastern axis of Singida region consist of a massive inland plateau with isolated mountains and numerous granite exposures from the Precambrian era that are suitable for archaeo-tourism [9].

\section{Ng'ongo A Gifandwa B (Elevation 1676 UTM 9458316)}

In the Ikungi district, shelters with rock art occur mainly in the highlands, and they are commonly scattered along the Precambrian granite rock outcrops of Singida region. In this huge rock overhang which is about $30 \mathrm{~m}$ tall, facing west towards Ughaugha A Village, there are few dusky red geometric paintings such as concentric rings which can be compared with the Hunter foragers art of Kondoa Irangi sites.

\section{Itramuka Rock shelter}

Itramuka rock paintings site is found in the Itramuka hills in Misimbwa hamlet of Siuyu Ward. The northeastern side of Misimbwa is dominated by scatters of isolated hills and rocks that continue eastward to join the Mugori rift escarpment. These hills and the associated rift escarpment is what is known as the Itramuka hills and escarpment, and is the location of the hunter-foragers faded 
rock paintings. The painting site is located on the footslope of the Itramuka rift escarpment overlooking Mugori valley. The site occurs on the escarpment's slope in woodland vegetation and has an approximate elevation of $1400 \mathrm{~m}$ a.s.l. This is a combination of a rock shelter and three overhangs, two exterior overhangs and one posterior overhang.

The shelters face south east and east, and it is at least $5.5 \mathrm{~m}$ long and $7.5 \mathrm{~m}$ wide from the modern drip-line to the back wall. There is a large rock (slab) underneath the shelter, which is climbable and may have been used by the painters as a scaffolding to paint the images high up on the shelter. The height of the rock shelter is about $7.5 \mathrm{~m}$ high. About six stone artifacts were spotted on the surface of the shelter's floor. The overhang faces east and is about $5.8 \mathrm{~m}$ long, $2.5 \mathrm{~m}$ wide and $7.4 \mathrm{~m}$ high. The painting subject matter includes naturalistic animals, humans, geometric, and amorphous or abstract figures (Plate 6). This is the most suitable site for public displays, and for tourist treks because the paintings are in a fair to a very good state of preservation.

\section{Discussion}

In both sites surveyed in this area, the "Hunter-foragers' paintings art" were discovered. This art tradition is represented by clarity, simplicity and their image edges are well refined, suggesting that they may have been painted with fine brushes [9]. Within this art tradition, another category which is composed of Hunter-foragers' red geometric art as the case of Ughaugha B sites was recorded. In most cases these two arts occur simultaneously, and are mostly depicted in a red or dust red monochromes. Paintings subject matters represented mainly naturalistic and semi-naturalistic wild animals or humans in stylized forms. Other subject matter included executions of birds, vegetation, handprints, and anthropomorphic, therianthropic and shamanistic figures that are expressing the dynamics of local environment and the essential needs of foraging communities as the case of Itramuka Rock shelter (Plate 6). Humans are depicted engaged in activities such as hunting, singing and dancing [9].

The second category of hunter-gatherers' art is represented in red geometric

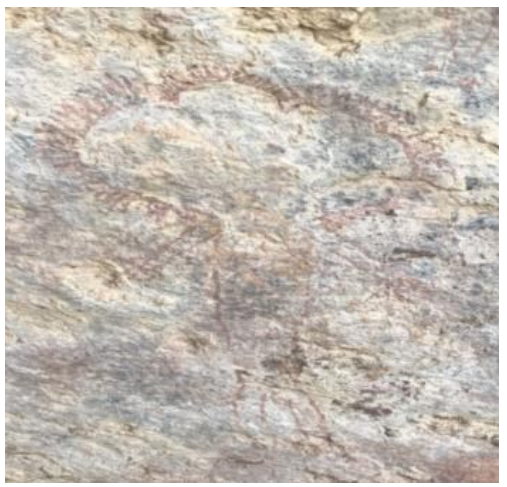

Plate 6. An execution of a shamanic figure: Stylized human figure at Itramuka rock Shelter (photo credit: Itambu 2016). 
designs that is commonly characterized by geometric designs such as concentric circles, parallel lines, horizontal lines, ladder-like lines, scaffolding-like, thought to represent the later phase of hunter gatherers traditions and they are constantly laid over the later paintings. In most cases, figures of this group appeared in association with other figures like human, animal or both. They are painted in various shades of red, especially, light, reddish brown and dark red colours. In Singida, such paintings appear in many parts with granite rock-shelters. Elsewhere in Tanzania, this art tradition is widely represented in Dodoma, Iringa, Manyara, and in the Lake Victoria Basin [9] [14].

At Itramuka rock shelter, there is an execution of a unique and huge humanistic figure painted in red pigments and it is about $30 \mathrm{~cm}$ tall; that any beholder could be able to interpret it as a very distinctive form of early religious belief systems. It is depicted by a stylized shamanistic figure (humanistic figure wearing a plume on head, spiky-head, very enormous head) (Plate 6). This can be attested to Shamanism-an early form of religious worships-beliefs that were practiced by the hunter-foragers since time immemorial. Our ancestors probably had developed the very strong cognitive thoughts on their ancestral spirits, or sorts of cosmological consciousness on the existence of the "supreme being" and the universe. This figure probably was a symbol of the one who created the universe, the "unmoved mover", the uncaused causer for whom they had descended from. Also, it probably portrayed the transcendent cause of the whole mankind and the preconceived essence of eternal life.

During that time, our ancestors could have been conscious and sensitive about the life after death, thus their beliefs were depicted in the forms of art with the stylized and schematized extraordinary human figures on rock shelters. This again gives us an understanding of the prehistoric peoples' lifeways regarding the beginning of belief systems. The beliefs on supernatural power, eternal life (spiritual beings) were probably emerged by that time and they presumably did worship this humanistic figure as it might have governed "their universe" and their daily life ways and the affordances of that time. It would also suggest an earliest evidence of rituals and religious ceremonies that took place to this site. Unlike other sites we did discover, this site contains none of archaeological artifacts an instance that suggest that the site was presumably utilized for ritual activities rather than being used as a settled shelter.

The paintings with geometric signs or symbols were also compared with ethnographic signs painted on ceremonial gourds of the Wanyaturu/Rimi people of Singida (Figure 3 and Plate 7). Among Wanyaturu signs engraved or painted on ceremonial gourds have symbolic meaning. For instance, cattle figures symbolize wealth; parallel and curved lines symbolize peace, fruitful marriage and as a symbol of fertility as well. Such signs and patterns are widely depicted in Ughaugha B sites, and are comparable to the ethnographic objects recorded among the Wanyaturu where it can be used as a sign of a link between the past and the present communities (See Plate 7). 


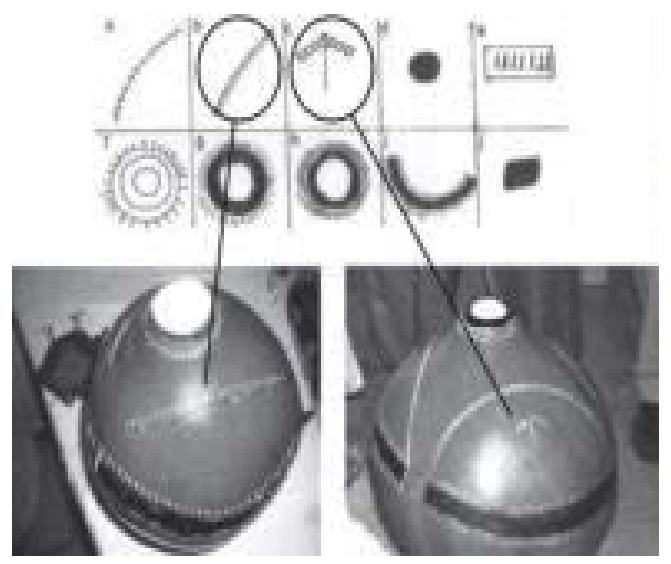

Figure 3. Paintings from Ng'ongo a Gifandwa A rock-shelter in comparison with signs engraved Wanyaturu ceremonial gourds.

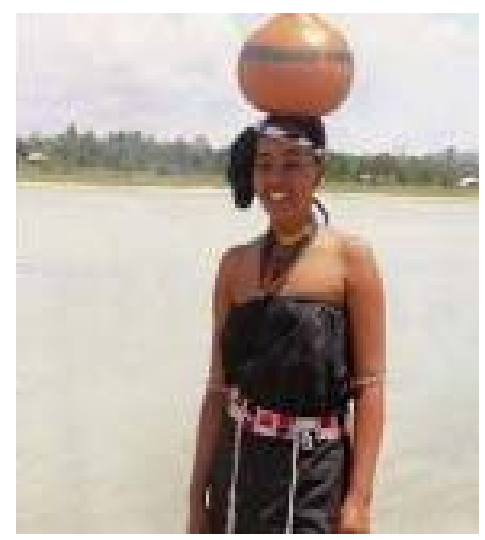

Plate 7. Paintings from Ng'ongo A Gifndwa B rock-shelter in comparison with signs engraved on Wanyaturu ceremonial gourds.

Unfortunately, most of the rock art of Singida region, as the case in the whole country are in adverse threat of total disappearance and are highly affected by physical weathering, as well as biological and anthropogenic actions. The common physical agents threatening paintings in this place are rock weathering, exfoliation and oxidization. Also, there are some biological threats that include vegetation growth on rocks, as well as birds and hyrax dropping.

Threats related to anthropogenic actions include graffiti and smoke that cause the formation of soot on paintings. The situation is worse at Misimbwa rock-shelter where most of the paintings are faded due to rock weathering and biological actions. Local people for instance, are becoming the biggest threat to the survival of the art presently. The lack of sensitization has made most local people in to believe that rock paintings are signs left by German colonialists to locate or indicate places of buried treasures. Therefore, treasure hunters are looking for German possessions in rock shelters with paintings. Such threats need serious mitigation measures; otherwise most of the paintings will disappear due to vandalism by treasure hunters and other activities of present day modernization such as encroachments [14]. 


\section{Concluding thoughts and cautionary notes}

Future research should consider waging more archaeological excavations under rock shelters in order to link central Tanzania (Singida and Dodoma), Northern Tanzania (Simiyu, Manyara, Arusha and region), and the southern Tanzania highlands (Iringa and Mbeya regions) in rock art research projects. These prospects should focus on providing public education on heritage management and conservation. This is one of the most significant tools that may lead public to increase their level of understanding about the significance of heritage sites such as the rock art [9] [15] [16]. Pro-bono training should be taken as one of the major milestones in insuring long-term success of cultural heritage management. It should integrate guidance in appropriate interpretation of cultural sites and allied objects, heritage management and tour guide workshops, and infrastructure development in Singida region. Whatever non-utilitarian cupules meant at any time in human history, they were an integral part of some symbolic system. They are the oldest artistic monuments of hominids that deterioration processes have left for us to see. They do not, however, define the earliest forms of palaeoart, as simplistic archaeological reasoning would suggest [15] [16].

\section{Acknowledgements}

We wish to express our sincere wholeheartedly thanks to the local people and informants of the Siuyu and Ughaugha villages who accommodated us with warm receptions, insightful ideas, invaluable support, and by showing to us the location of the archeological sites. These informants are: Xaud Dagharo, Charles Joseph Ndhobho, Fr. Tom Ryan SCA, Qiimu Senani, Mourice Moukhotrya, Ambrose Leo Deede, and Thomas Telesphory Mungwabi, and the research crew cooks' namely Anisia M. Nkhalehe, Martha P. Itambu, and Magreth M. Ghuliku (Mwajîfya inno ahumba na ancha va ukhaya!). Again, we would like also to express our sincere gratitude to the University of Dar Es Salaam Archaeology class of 2016 who worked momentously with us during their Archaeological field practicum training in Singida region.

Thank you so much to you all my brothers and sisters, your valuable contribution to the success of the manuscript is highly appreciated.

\section{Disclosure}

The authors report no potential conflict of interest.

\section{References}

[1] Masao, F.T. (1976) Some Common Aspects of the Rock Paintings of Kondoa and Singida Central, Tanzania. Tanzania Notes and Records, 77-78, 51-64.

[2] Ekeke, F. (2010) Transition from Later Stone Age to Iron Age in Northern Singida District-Central Tanzania. Unpublished MA Dissertation, University of Dar es Salaam, Dar es Salaam.

[3] Itambu, M.P. (2013) The Rock Art of Iringa Region, Southern Tanzania. A Descrip- 
tive and Comparative Study. MA Dissertation, University of Dar es Salaam, Dar es Salaam.

[4] Itambu, M.P. and Bushozi, P.G.M. (2015) The Rock Art of Iringa Region: Studies in the African Past. The Journal of African Archaeology Network, 11.

[5] Itambu, M.P. (2015) Rediscovering the Intriguing Patrimonies Depicted in Rock Shelters of Iringa, Tanzania. In: Runge, J., Ed., Changing Climates, Ecosystems and Environments within Arid Southern Africa and Adjoining Regions. Palaeoecology of Africa 33, CRC Press, London, 175-190. https://doi.org/10.1201/b19410-1

[6] Itambu, M.P. and Hongoa, N.M. (2016) Archaeology and Heritage Resource Management in Siuyu, Singida Region (Tanzania). Journal of Geoscience and Environment Protection, 4, 34-45. https://doi.org/10.4236/gep.2016.46003

[7] Itambu, M.P. (2017) Integrating Rock Art Heritage Conservation with Eco-Tourism Promotion: The Case of Iringa Region, Tanzania. UNESCO Proceedings. African Heritage and Pillars of Sustainability.

https://heritagestudies.eu/proceedings-african-heritage-and-thepillars-ofsustainabili ty/\#more-3836

[8] Leakey, M. (1983) Africa's Vanishing Art: The Rock Art of Tanzania. Doubleday and Company, New York.

[9] Mabulla, A.Z.P. (2005) The Rock Art of Mara Region, Tanzania. Azania: Archaeological Research in Africa, 40, 19-42.

[10] Masao, F.T. (1976) The Later Stone Age and Rock Paintings of Central Tanzania. $\mathrm{PhD}$ Dissertation, University of Simon Fraser, Burnaby.

[11] Itambu, M.P. (2016) Managing the Balance: Ecological Pressures and Heritage Resources in Rungwe District, Southern Highlands of Tanzania. Journal of Geoscience and Environment Protection, 4, 79-90. https://doi.org/10.4236/gep.2016.43007

[12] Christiansson, C. (1972) Notes on Morphology and Soil Erosion in Kondoa and Singida Districts, Central Tanzania.

[13] Saanane, C.B. (2016) Cultural Heritage Assets: Rituals, Grinding Hollows and Other Socio Cultural Practices in Simiyu Region, Tanzania. Natural Resources, 7, 214-238. https://doi.org/10.4236/nr.2016.74020

[14] Bushozi, P.G.M. (2014) Towards Sustainable Management of Cultural Heritage Resources in Tanzania: A Case Study from Kalenga and Mlambalasi Sites in Iringa.

[15] Bednarik, R.G. (1994a) Art Origins. Anthropos, 89, 169-180.

[16] Bednarik, R.G. (2002) About the Age of Pilbara Rock Art. Anthropos, 97, 201-215. 


\section{Appendix 1. Archaeological Findings from the Surveyed Sites}

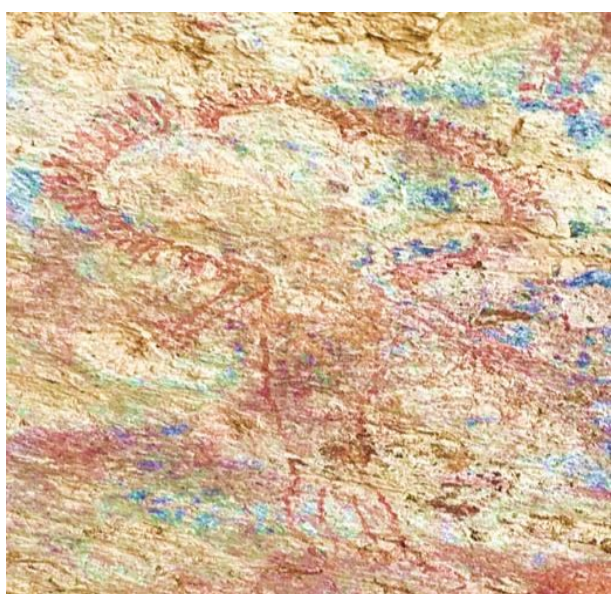

(1) Rock paintings

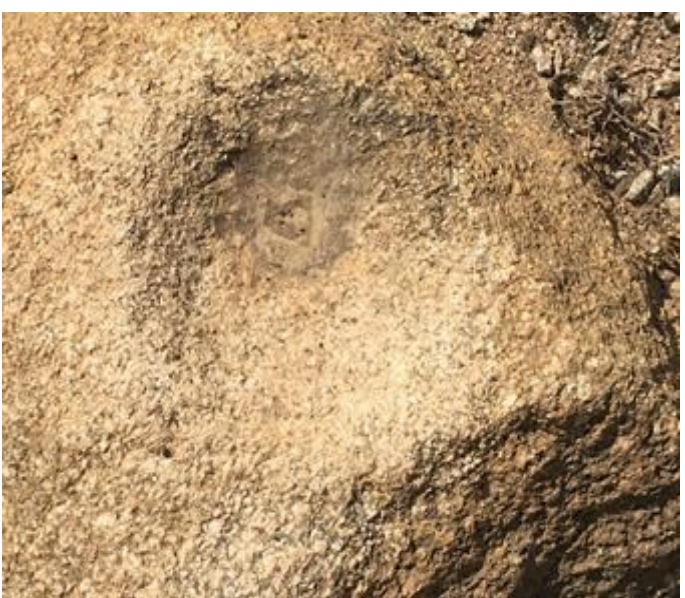

(2) Grinding hollow

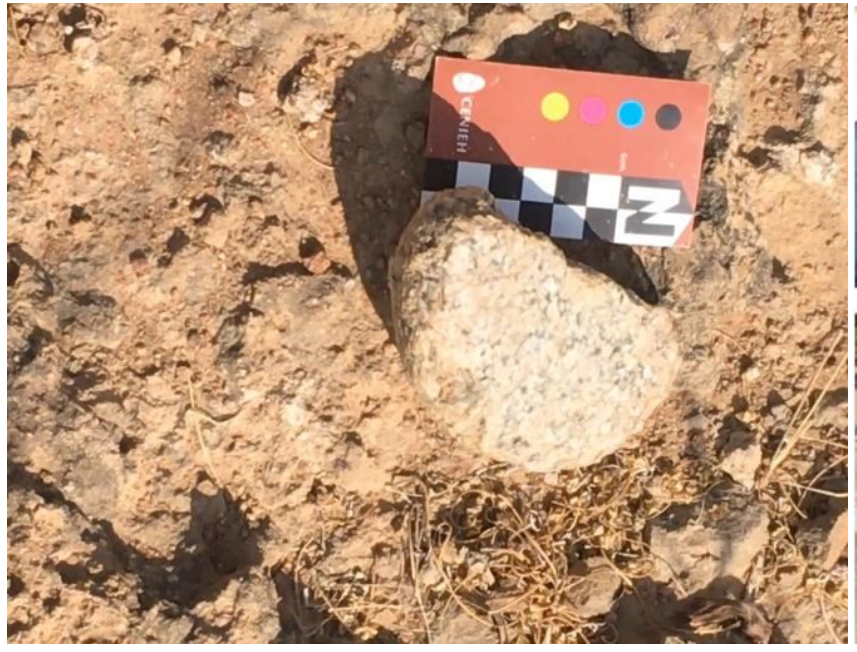

(3) Mortar
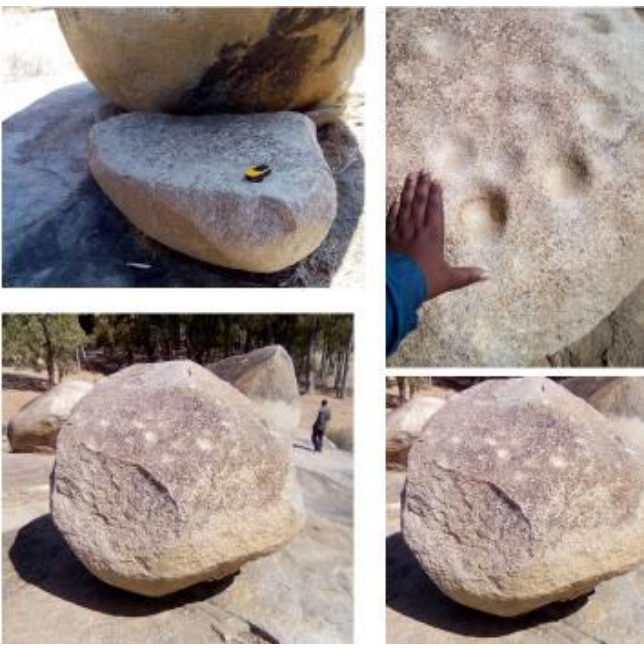

(4) Cupules

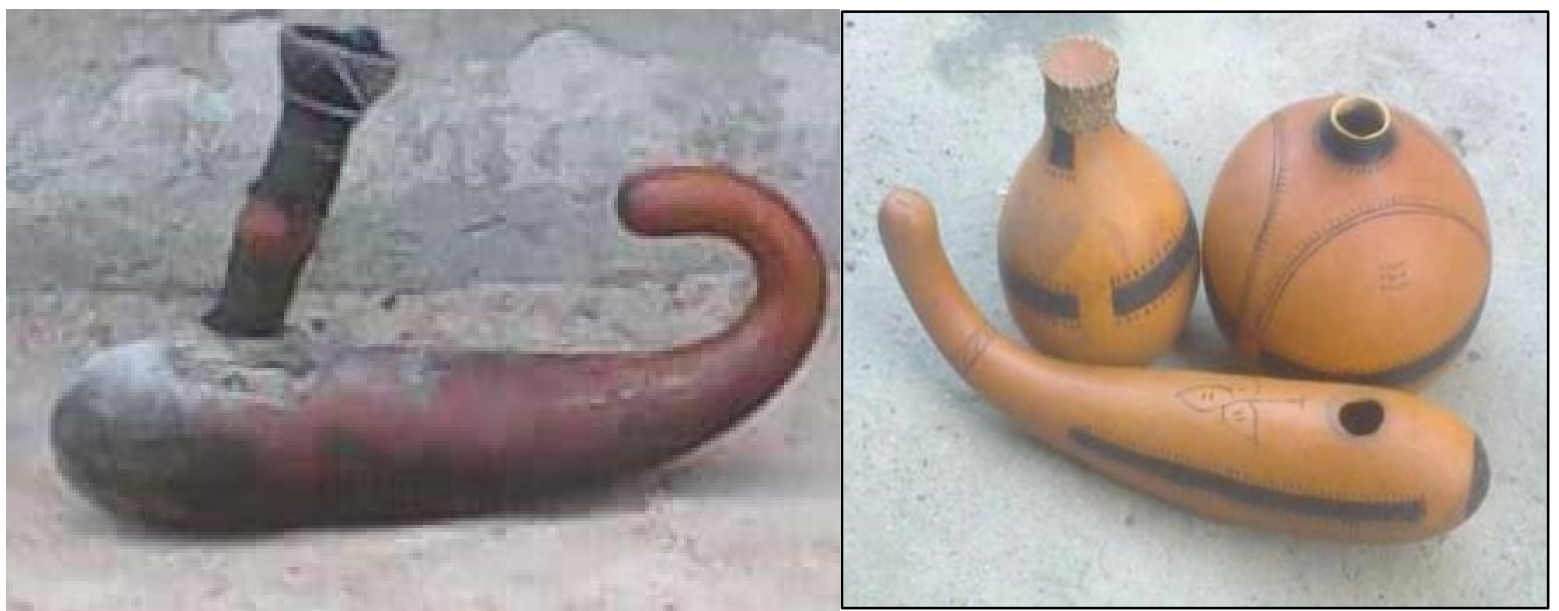

(5) Rimi ethnographic utensils with decorations like the hunter-foragers' art friezes 


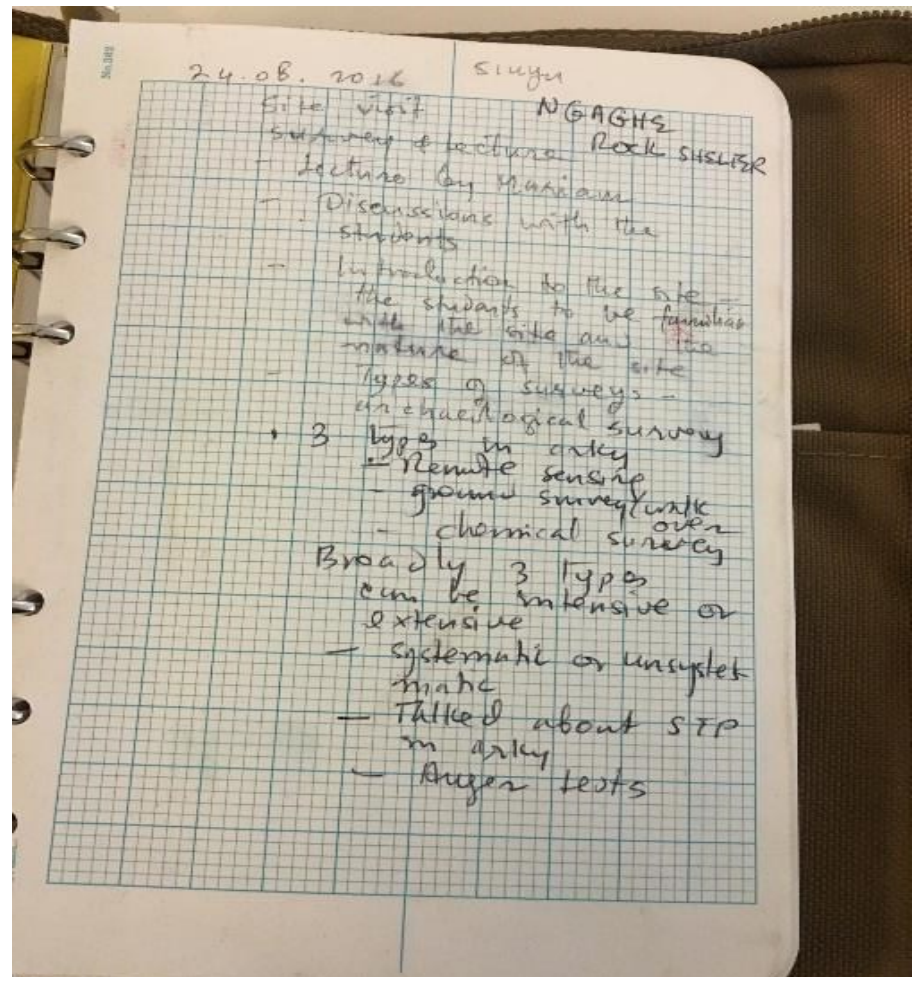

(6) Field notes 